\title{
Life Writing Research Past and Present: Interview with Sidonie Smith and Julia Watson
}

\author{
Sarah Herbe \\ Department of English and American Studies, University of Salzburg \\ Julia Novak \\ Department of English and American Studies, University of Vienna
}

\section{INTRODUCTION}

On 16 November, 2017, the Austrian "Netzwerk Biographieforschung", ${ }^{\text {a }}$ network of life writing scholars and practitioners from various disciplines (history, literary studies, pedagogics, archival work, art, musicology) hosted its twelfth workshop at the University of Music and Performing Arts, Vienna. The organisers (Sarah Herbe, Julia Lajta-Novak and Melanie Unseld) were delighted to welcome two very special guests: Prof. Sidonie Smith and Prof. Julia Watson, whose vital contribution to autobiography theory need hardly be explained in the context of this journal. They had been invited on the occasion of the recent publication of Life Writing in the Long Run: A Smith and Watson Autobiography Studies Reader (Maize Books, 2016, available free online), which features a cross-section of their scholarship in the field over three decades.

The following is an excerpt from the interview Sarah Herbe and Julia Lajta-Novak conducted with Sidonie Smith and Julia Watson, which addressed the differences between autobiographical and biographical modes, recent theoretical interventions in the field of life-writing studies, and topical issues such as the impact of "post-truth" on auto/biography scholars and the implications of the \#MeToo movement as a massive autobiographical project.

This work was supported by the Austrian Science Fund (FWF) under Grant V543-G23. 


\section{EINLEITUNG}

Am 16. November 2017 fand an der Universität für Musik und Darstellende Kunst in Wien der zwölfte Workshop des österreichischen „Netzwerk Biographieforschung", im Rahmen dessen sich VertreterInnen aus Literaturwissenschaft, Geschichte, Musikwissenschaft oder Pädagogik halbjährlich interdisziplinär über Fragen der Auto/Biographieforschung und Praxis austauschen, statt. Zu Gast bei diesem von Sarah Herbe, Julia Lajta-Novak und Melanie Unseld veranstalteten Workshop waren Prof. Sidonie Smith und Prof. Julia Watson, deren zentrale Beiträge zur Autobiographietheorie in diesem Rahmen nicht weiter vorgestellt werden müssen. Sidonie Smith und Julia Watson waren anlässlich der Veröffentlichung ihres online frei erhältlichen Sammelbandes Life Writing in the Long Run: A Smith and Watson Autobiography Studies Reader (Maize Books, 2016) eingeladen worden.

Im Rahmen des Workshops führten Sarah Herbe und Julia Lajta-Novak ein Interview mit Sidonie Smith und Julia Watson, das im folgenden auszugsweise widergegeben wird. In diesem Interview wurden Unterschiede

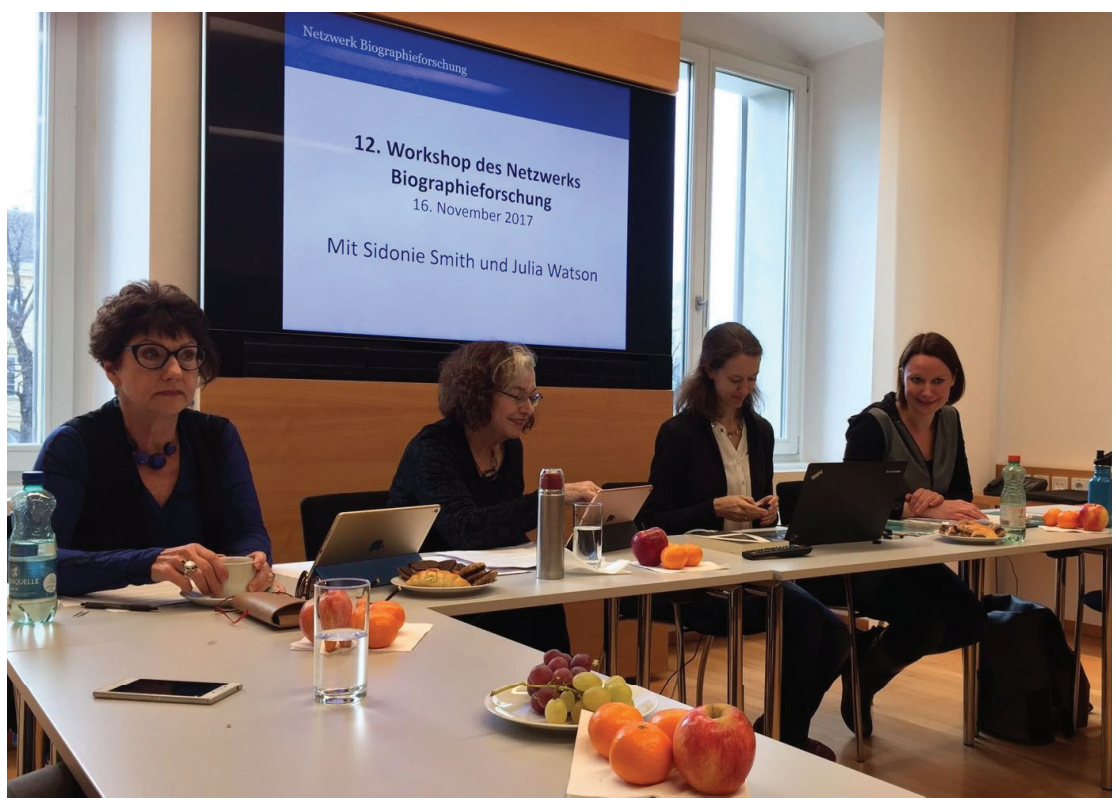

From left to right: Sidonie Smith, Julia Watson, Julia Novak and Sarah Herbe (Photo (C) Sandra Mayer) 
zwischen autobiographischem und biographischem Schreiben angesprochen sowie rezente theoretische Entwicklungen im Bereich der Life-Writing Studies diskutiert. Darüber hinaus kamen aktuelle Themen wie die „Post-truth” Debatte und die \#MeToo Bewegung als autobiographisches Massenprojekt zur Sprache.

Sarah Herbe (SH): In Reading Autobiography (2001; 2010), you see the term life writing as denoting self-life-writing, mostly. But recently it seems to have come to stand for both autobiographical and biographical narratives. We would be interested to hear to what extent you see the two modes as separate-and therefore requiring distinctive research methods-and to what extent would you say they speak to each other and ought to be treated collectively?

Sidonie Smith (SS): One of the obvious distinctions between the two forms is that, while there is an 'I' in a biography, that 'I' of the biographer is generally assumed to be positioned outside the world that's being constructed. In some interesting experimental biographies, the "I" of the biographer enters into the biography, but, by and large, readers are not cued in that what we are reading about, or reading for, is how the "I" of the biographer constructs her- or himself. It's also true that biographical portraits are often embedded in autobiographical projects; but the main project of the autobiographical narrator is not to produce an objective or larger portrait of a related or referenced other. These entanglements of the autobiographical in biography, and of the biographical in autobiography, suggest how the two forms are related to one another, but call for distinct theorizing and distinct methodologies.

Julia Watson (JW): As John Eakin suggested long ago, autobiographical and biographical projects share what he calls "referentiality," that is, they refer to an externally existent world, unlike fiction, where the reference is of verisimilitude to a possible world. But, at the same time, the question of verification-how one investigates the truth of what is claimed-is very different in biographical than in autobiographical texts. As those of you who work on biography know, it's very important to check the facts, have them be as accurate and complete as possible, and subject them to the approval and verification processes of others in your field, even though controversies may arise at critical points. But, for the autobiographical, in some ways the standard is subjective truth; in extreme examples the autobiographical can include lies, either deliberately, as a way of testing the reader, or as reflecting a change of mind-it seemed this way at this point, but a different way at another point. And while a biographer might try to approach the dynamism of her or his subject by reflecting changing 
views on a topic, they have to situate that very differently than an autobiographical writer does.

There are other aspects concerning your question of methodology. Recently, when we developed a paper on archives with the title, "The archives of those who write themselves," we realized that, for people who work as biographers, one project is to learn what autobiographers have long focused on: how to read autobiographical texts. A starting point is that those texts are not transparent; that is, the literal truth of everything claimed in an archival letter, document, etc., should not be taken as an absolute standard of truth. These texts need to be interpreted, and acts of interpretation are very different from the recording of fact. Our paper takes up eight examples of what is involved in reading archival autobiographical texts, and there could be many more. As we thought about it, it became interesting and complicated to consider, How do you read someone's diaries? Or their letters? In those to so and so, do they make very different claims than in their letters to someone else? That is, the subject both is and is not to be trusted. For biographers, often one is situated within larger conversations or dialogues with groups of scholars with whom one identifies or against whom one positions oneself. In such cases the biographical I-more strongly than the autobiographical-draws authority objectively from its identification with a particular school of analysis or against another in ways that are both ideological and theoretical.

SS: It is a kind of disciplinary I, with the I of the disciplines speaking.

Julia Novak (JLN): We'll move on to something quite different now. As life writing appears in so many different genres and media, formats, places, it can almost be conceived as a sort of super-genre today, that pervades our postmodern world, especially since the rise of the Internet. The study of life writing is therefore also always a study of broader social developments and of the shifts in our social value systems. If I look at the work which you have done on life writing in the past three decades, it often picks up on very topical issues. How important has it been for you as scholars to follow current developments in and through life writing? I'm thinking of your work on women's life writing, for example, or story-telling in the context of human rights.

SS: This is one of the things that has been wonderful about our collaboration. It's sometimes harder for an individual to see what horizons are just coming into view in one's field. But together, we've tried to figure out what is the "next big thing" on the horizon of autobiography studies and then address it in a collection of essays. An example is our first anthology, De/colonizing the Subject (1992), which may still be our most important collection. Although postcolonial studies was in a ferment in the later 
eighties and early nineties, no one in autobiography studies was thinking about the multiple processes of decolonization around the world.

JW: In relation to women!

SS: ...in relation to women. Another important thing about the projects we take up is that doing an anthology means you have to find other people in the field whose work will push some boundaries in a new way. So, we were educating ourselves every time that we did a new project because we had to learn about its complexities in the process of identifying contributors and editing their work. One difficulty now is that many presses no longer publish collections of essays, as they did in the United States in the nineties. Back then, there was a cloud of activity, with all these people focused on the same topic working on the green screens of the old computers and collectively producing knowledge in new areas. That was a really exciting time! Trying to be out in front allowed other scholars to teach us and take us to new horizons in autobiography studies.

JW: Often we did this by going outside the disciplinary fields in which we were situated. Sidonie and I both have PhDs in literature, hers in English, mine in comparative. But there's a tendency among literary scholars to both claim the autobiographical as writing and to reject it as non-literary—at the same time! It's different in sociology or communication studies, or education or psychology, or theatre, music, and the visual arts. And the notion of what constituted autobiographical projects implied separate canons that do not align well across disciplines. The other thing I would say is, we were working at a special time when interest in memoir was growing rapidly with what was called "the memoir boom," in various ways an international phenomenon. And we worked in autobiographical rather than biographical projects predominantly because the biographical is more situated in history than in literature. At that time, a kind of reciprocity often existed between theoretical positions and personal texts. Suddenly, some assertions that had seemed unquestionable as the basis of theory began to shift-questions of the author, the subject, experience, agency. Similarly, the rise of trauma studies and the related focus on human rights began to profoundly affect the theorizing of autobiography.

Another example in the US is the recovery of slave narratives and captivity narratives, which changed what we thought was autobiographical storytelling, particularly with "as told to" narratives. We could go on with similar examples. In the histories of biography as a field, things have unfolded somewhat differently, perhaps because there is anxiety about, or resistance to, reinventing the field, and a greater embrace of established standards. In autobiography studies, by contrast, if anything, people are 
so forward-looking that new generations of scholars may not want to read anything older than ten years. We find ourselves in the somewhat paradoxical position of saying to students, "You really should go back and read Lejeune. You really should refrain from claiming that you are the first one to have invented those interesting coinages such as 'autogynography'... That term was around in 1980; it didn't start in 2015."

JLN: As you mentioned De/colonizing the Subject, in the introduction to your reader Women, Autobiography, Theory (1998) you map scholarly engagement with women's autobiographical practices and you "propose prospects for future inquiry in feminist critical investigation." The reader was published in 1998 and it has since become an important point of reference for work in the field. In the Introduction, you diagnosed autobiography "until recently" to be "a primarily masculine domain." Now, since 1998, women's autobiography has been a field of prolific cultural production, and also, many of the avenues for critical inquiries into women's autobiography to which you pointed have since been taken up by scholars. What would you identify as the most important interventions in the field at large since?

SS: Some kinds of life writing that have generated energy since 2000 are: trans writing, the trans subject and its relationship to the gendered subject, and the sexed subject. There is also a lot of interest among writers and students in what is called eco-autobiography or eco-autobiographical writing, which situates the self within the landscape and investigates questions of sustainability. I had a student who did a project on toxic subjects and the environment. Other new areas in the United States are: crips-ofcolor critique, disability studies, and precarity narratives. These involve not only writing about illness narratives, but also elaborating theoretical frameworks that develop from intersectional analyses. There is also a lot of work now on graphic memoir.

JW: Especially because there is such an explosion of texts...

$\mathrm{SS}$ : And there is a lot of interest in online modes, raising questions about thing/thingness/materiality, and how it witnesses.

JW: Take, for example, the embroideries left by refugees from South Asia detained on the island of Nauru outside Australia, that our colleague Gillian Whitlock writes about. Such material texts are by people who either do not write or are not interviewed and whose stories are not recorded-in what ways may their "things" speak? Life narrative studies has expanded automedially to consider self-representation in the arts and film. And at this moment there is renewed focus on migration studies, which may actively involve oral interviewing, raising the issue of how to deal with 
refugee testimonies. Clearly this focus is urgent and will, one hopes, have some interventionary power. Our field is so dynamic that keeping up is really a challenge!

SS: One of the interesting and important trends in the field now is rethinking trauma narrative frameworks outside a psychoanalytic model by addressing real situations and the movement of people around the globe from cultures outside the West. For instance, how might scholars think about the oral histories of migrants, and connect them to activist movements? how could they be framed effectively by epitexts and paratexts?

JW: There is also the crucial relation of translation studies and language issues to this area, which can be a tremendous challenge, say, with migrants from African countries.

SS: There is also a diverse array of post-humanist projects going on, people who are interested in trans-species life writing, in animal studies or the technical side of the post-humanism. Some people-and I am one of them-are working on assemblage theory, how to get away from the singularity of the text and the singularity of the subject, and think about the distribution of agencies across an assemblage of actors and materials in the production of identities and selves.

SH: We will now come to the question of digital life writing, because that's been mentioned a couple of times now already. In "Virtually Me: A Toolbox about Online Self-Presentation" (2014) you introduce "analytical frames and theoretical positions of scholarship on life writing" in the form of fifteen concepts in alphabetical order, "to enable scholars and students to productively engage with the vast variety of sites presenting lives online." To what extent do you feel that online self-presentation can be subsumed under previous concepts of life writing and hence studied through the same lens and to what extent has the www changed the game and we require novel methodologies for the study of online life narrative in whatever form?

JW: I suppose our response is "both/and." Our essay was produced some years ago and we knew, even as we were writing it, that it would be obsolescent by the time it was published; in the three years it has been out, much has changed. With some aspects of online writing, particularly blogs, crucial tools to help think about issues such as identity, agency, and theorizing memory are often not taken into account when discussing the seeming continuous present and interactivity of social media. In that sense the sites of online writing are quite different. Certain aspects of online life writing focused on the self are entirely different than when the norm was only analog life writing. For example, the central concept of 
the brand, how people have to shape themselves as their brand and conform themselves to public norms to become legible online. Or take the quantitative-self movement online, which has affected many subgenres of memoir and practices of life writing. In it, the self-tracking one does every day may be seen as more revelatory of who and what a person is as a social being at a particular moment in time and place than that person's introspective disclosures. That is, online forms are generating pressure to rethink what we mean by self-presentation.

SS: Scholars working in autobiography studies can now engage concepts articulated in media studies such as context collapse, surveillance, dataveillance. There are also interesting hybrid movements that toggle between online and offline modes of self-representation. John Zuern recently presented an excellent keynote on the issue of people who gain a kind of a mini-celebrity online and then produce autobiographical narratives that, when published as books, enhance the celebrity of their online selves (at the London meeting of the European IABA conference in June 2017). In fact, the question of what celebrity is, how to understand its production and think about fandom, and the relationship of life writing to fandom are very productive sites to examine. Or think, for instance, about the field of autobiographical gaming in which creating a fantasy life story may enable the users of the game to inhabit a synthetic life but experience it as their own. That creates an interesting set of questions: "What does empathy have to do with gaming? How adequate are the terms or processes of identification in such contexts?"

JW: We could project fantasy avatars, for example-already a strange phenomenon.

SS: We shouldn't jettison what we know from analyzing life writing in offline forms, but at the same time those analyses are not adequate to understanding what is going on online.

JLN: Sidonie, in "Narratives and Rights: Zlata's Diary and the Circulation of Stories of Suffering Ethnicity", an essay that you published in 2006, you discuss a central perspective of life writing today: narratives of suffering that originate from ethnically motivated human rights violations. And the example you analyse is Zlata Filipović's Zlata's Diary: A Child's Life in Sarajevo, which, as you say, is framed as a kind of Yugoslavian Anne Frank tale with a happy ending. You point out that the way in which such individual personal narratives come to be framed as stories of universal suffering actually works to obscure their historical complexity and places the subject unambiguously in the position of innocent victim. Would you say that this kind of simplification is somehow 
necessary, in terms of subject position and in terms of drawing on a readily available meta narrative, that it is the price that must be paid to guarantee the broad appeal of such stories of suffering, and that it is hence necessary for the functioning of their ethical message, for producing the effect that authors and publishers hope for-empathy for the suffering? In which case there is no way out of this conundrum, or is there...?

SS: I would answer that in two ways: Yes, it is necessary. And yes, the facts are very problematic. When Kay Schaffer and I published Human Rights and Narrated Lives, we started out with a concept of the right to narrate one's story, which privileged the importance of testifying to one's own experiential history, to one's own victimization. But the more we looked into how these first-person narratives of suffering are drawn into the human rights regime, the gloomier our analysis became. Because, by entering that arena, only certain kinds of stories will gain efficacy. And only certain parts of people's stories will be usable. Take, for instance, the collections of narratives put together of the women who endured sexual slavery during WWII in countries under Japanese occupation, sometimes called "comfort women." They had to tell that story of dehumanization to get it to the public, and to energize and feed an activist movement. It was very important because, if they hadn't come forward, nothing would have happened. But after they came forward, their stories were packaged in a common framework, with a common narrative schema: All of them had to tell about when they were taken from their families, their entry into the comfort station, what happened to their friends, the end of the war and return to communities and families in which they were ostracized-all of that had to be witnessed. But in the process of narrating this story for the activists who assembled the collections, some of the women, who had travelled around the world telling their stories over and over on college campuses, spoke of how they were retraumatized by continually having to produce this story. The conditions under which the stories must be told catches them in a set of imperatives about storytelling and the commodification required to be effective and compel empathy from listeners. That is, in human rights movements at the moment, there is a need for the stories told to capture an audience and raise money for campaigns. But both the cost and the effects of this form of witnessing can be disturbing.

JW: One other thought: We proposed, at the end of our "Witness or False Witness" essay that readers try to read differently. There is an understandable desire- that we share-to redress the desperate suffering of people around the world by reading their narratives as a way of becoming vicarious witnesses to this suffering, and to empathize, send money, pass along 
their books, create aware communities. But often this vicarious participation in narratives of suffering does not change the structural conditions under which such abuses thrive. Therefore, a different kind of reading is needed. Readers might bring more critical stances to rights narratives and to the complex webs of expectations into which they enter, with templates that are generated by particular presses. Non-naive reading, it seems to us, is part of what is at stake here.

SH: You have already mentioned "Witness or False Witness?: Metrics of Authenticity, Collective I-Formations, and the Ethic of Verification in First-Person Testimony" (2012). In this essay, you deal with the question of whether these witness narratives are verifiable, what ethics of verification we need, but then you also come up with the question whether it is actually always that important that everything is an accurate account of what happened, or whether it's not more important to talk about the issue in the first place-you address child soldiers as you mentioned before, and the question whether this was really a child or not, but the fact that child soldiers as a phenomenon exist is maybe more important than the verification of the individual case. The article was published in 2012 before "post-truth," "post-factual" made international headlines, and I was wondering whether this idea of post-truth or the post-factual has now come to affect your reception or our perception of witness narratives in any way, or in life writing in general, because I sometimes see this as a problem, also when we talk about the constructedness of stories in connection with these ideas...

SS: There are a couple of ways to think about this. For instance, in the US we can recall the case of slave narratives, which were challenged as false almost every time they were written. The allegation was that, if escaped slaves could write a narrative, they couldn't have been enslaved, a definitional undercutting of the form. Another charge was that slave narratives were really written by white benefactors in the North. For a long time, certain kinds of narratives have drawn suspicion because powerful interests are invested in not having readers believe their stories. In that sense, this moment of post-truth also applies to earlier times. Think about the witch trials in the American colonies-they were post-truth witnessing, too. But it's also the case that this historical moment, the Trump era, is a new one for us, that's for sure.

JW: Yes, now with anything people don't believe, they say "Fake news!" And scholars of life writing may be in a difficult position to speak because it is mortifying to be attached to a "fake news" framework. Also, there are always what we called in the "False Witness" essay "detectives of suspicion," people searching for problems in narratives claiming to be "true." 
We might think about this issue in another way. One of the projects I've worked on in various essays for a long time is Life? or Theater?, the massive narrative in painting and writing by Charlotte Salomon, that has been remediated in many modes-plays, opera, seven films, etc. In a 2011 Dutch film by Frans Weisz, just called "Life? Or Theatre?", a longsuppressed section of a letter at its end was incorporated, which added a shocking allegation that I don't want to discuss now but that would change her status as both a sympathetic artist and as someone whom many have regarded predominantly as a victim of the Holocaust. This example raises a problem: How does one engage with additional evidence from a previously suppressed archive? For some critics this was only a matter of saying "Look! Everybody earlier was wrong. So, what do you think now?" But another response is to say that things are not simply factually true or false, particularly in written documents. These are utterances to be investigated in terms of the rhetorical situation in which they participate. And a letter is a form of address to a particular person with a certain objective. In the Salomon text, it is situated within the fictions of that text and needs to be interrogated accordingly. I am working on an essay that challenges the easy leap to something called "the new truth." To me, that's a series of false deductions derived from a newly ambiguous text that calls for further reading and understanding that may produce a better story. So, one kind of response is to move away from the truth/lie or fact/lie binary, to disarticulate fact from truth. They are not the same thing.

JLN: My next question is about \#MeToo, which can be seen as a massive autobiographical project. It's grounded in personal experience, it has an element of collectivity, and what $I$ found interesting was that critics of the movement say that as a movement, it makes claims for the universal victimhood of women, in opposition to man as a dangerous perpetrator. And I was wondering, that criticism seems to imply that this is a way of going back to a very old mode of feminist critique, one that roots notions of femininity in common experience. I was wondering what you think about \#MeToo.

JW: A useful framework for thinking about "MeToo" might be through strategic essentialism, a feminist concept from the early nineties, rather than reading such stories as testimonies of collective victimhood. That is, telling such a story is a strategic means of identifying with other women in this moment for disclosing narratives that were previously untellable in public institutional and work venues, where they can be heard supportively and without judgment. I think "MeToo" is also fueled by anger and the desire for a collective formation. While I'm uneasy about some aspects of such storytelling, I also think it's terrific. 
SS: It's a kind of "fuck you" statement, and might be read as exhaustion with the fact that "Yes! This happened to me." Often, when anybody spoke out, the position of victimhood was imposed on them as a way to silence women again. It's a shortcut way of saying, "Been there. Done that. Me too." It's both a gesture of solidarity and an in-your-face way of saying, "Come back at me if you want." Harassment has been happening for so long that we need a shortcut now, because it must be continually known.

JW: And we will tell on you.

SS: And we will tell on you!

JW: "MeToo" may generate some interesting autobiographical projects, particularly collective ones in film and video.

SS: Collective biographical projects by women about these men. Some crowdsourcing of the sexual history of so and so.

JLN: And I think we will conclude this interview with one quick question that is also a huge question in some sense. If you look back on the lifewriting research of the past three decades, have there been developments in the field that you see critically? And also, on a more positive note, are there areas where you think more research ought to be done?

SS: What I am critical of and feel annoyed about is when students come in to talk to me about their projects and treat their subject as if there isn't a history of the field. I think that probably happens a lot because there aren't many departments that think that life writing is important to include in the curriculum; that's certainly true of English departments in the United States. No student would present an idea about Shakespeare as if no one else had ever written about him. But in life writing, there is an annoying propensity to propose ideas that aren't new within the history of autobiography studies. I just say, "Go read, then come back and talk to me."

JW: When you teach life writing in courses, the first project is often to say, "Let's engage some of your assumptions and unpack them to consider why it might be useful to rethink some of them about who this "I" is. Is the "I" utterly to be trusted? And as simple as she or he seems?" That's an ongoing project. We don't see any past scholarly production in life writing as negative. This is a dynamic field with tremendous growth. Even four years ago I wouldn't have thought about some areas, such as the importance of migrant narratives, with the urgency that I do now. A decade or so ago I wouldn't have thought, "Hmm, autobiographical comics are a field that need to be theorized." To us, projects for future research are always a good idea. We try to end all our books with "Projects for future research" and the invitation, Join us! 


\section{WORKS CITED}

Smith, Sidonie, and Julia Watson. Life Writing in the Long Run: A Smith Ẽ Watson Autobiography Studies Reader. Ann Arbor, Michigan: Maize Books, 2016. https://quod.lib.umich.edu/m/ maize/mpub9739969/1:12/--life-writing-in-the-long-run-a-smith-watson-autobiograph y? rgn=divl; view=fulltext.

Smith, Sidonie, and Julia Watson. "Witness or False Witness: Metrics of Authenticity, Collective I-Formations, and the Ethic of Verification in First-Person Testimony." Biography 35.4 (2012): 590-626.

Smith, Sidonie, and Julia Watson. De/colonizing the Subject: The Politics of Gender in Women's Autobiography. Minneapolis: University of Minnesota Press, 1992.

Smith, Sidonie, and Julia Watson. Reading Autobiography: Interpreting Life Narratives. 2nd ed. Minneapolis: University of Minnesota Press, 2010.

Smith, Sidonie, and Julia Watson. Women, Autobiography, Theory: A Reader. Madison: University of Wisconsin Press, 1998.

Smith, Sidonie, and Julia Watson. "Virtually Me: A Toolbox About Online Self-Presentation." Eds. Anna Poletti and Julie Rak. Identity Technologies: Constructing the Self Online. Wisconsin Studies in Autobiography. Madison, US: University of Wisconsin Press, 2014. 70-95.

Smith, Sidonie. "Narratives and Rights: Zlata's Diary and the Circulation of Stories of Suffering Ethnicity." Womens Studies Quarterly 34 (2006): 133-152.

\section{ABOUT THE AUTHORS}

Sarah Herbe is associate professor of British literature and culture at the department of English and American Studies, University of Salzburg. In 2017, she completed her habilitation thesis on paratextual life writing in English poetry books. Recent publications include a co-edited collection on British Autobiography in the 20th and 21st Centuries (with Gabriele Linke 2017) and an essay on "Teaching Life-Writing in a Blended Learning Environment" (a/b: Auto/Biography Studies 2018). For more information, see https://uni-salzburg.at/ang/herbe. E-mail: sarah.herbe@sbg.ac.at

Julia Lajta-Novak is an Elise Richter Research Fellow at the Department of English, University of Vienna. She is currently working on a book project on biographical novels about historical women artists and is the author of Gemeinsam Lesen (Lit 2007-a book on reading groups) and Live Poetry: An Integrated Approach to Poetry in Performance (Rodopi 2011). She has recently co-edited Experiments in Life-Writing (Palgrave 2017) and serves on the editorial boards of the European Journal of Life Writing and The Journal of Historical Fictions. www.julianovak. at

\section{NOTE}

1 See https://biographieforschung.univie.ac.at/biographieforschung/. 